\title{
ERRATUM
}

\section{The financial cost of optimising blood pressure control}

T Shiner, L Simons, H Parkinson, G Nandhara, VJ Karthikeyen, A Khanbhai and DG Beevers

Journal of Human Hypertension (2006) 20, 382. doi:10.1038/sj.jhh.1002019

Correction to: Journal of Human Hypertension (2005) 19, 849. doi:10.1038/sj.jhh.1001938

Since the publication of the above-mentioned Corrigendum for 'The financial cost of optimising blood pressure control', it has been noted that there was an error in the order of the author names and in the spelling of one of the names. The corrected author list is as follows:

T Shiner, L Simons, H Parkinson, A Khanbhai, VJ Karthikeyan, G Nandhara and DG Beevers. 